\begin{tabular}{|l|l|l||}
\hline \multicolumn{2}{|c|}{ PublisherInfo } \\
\hline \hline PublisherName & $:$ & BioMed Central \\
\hline \hline PublisherLocation & $:$ & London \\
\hline \hline PublisherImprintName & $:$ & BioMed Central \\
\hline \hline
\end{tabular}

\title{
Cancer drug resistance
}

\begin{tabular}{|l|l|l||}
\hline \multicolumn{2}{|c|}{ ArticleInfo } \\
\hline \hline ArticleID & $:$ & 4130 \\
\hline \hline ArticleDOI & $:$ & $10.1186 /$ gb-spotlight-20010626-01 \\
\hline \hline ArticleCitationID & $:$ & spotlight-20010626-01 \\
\hline \hline ArticleSequenceNumber & $:$ & 201 \\
\hline \hline ArticleCategory & $:$ & Research news \\
\hline \hline ArticleFirstPage & $:$ & 1 \\
\hline \hline ArticleLastPage & $:$ & 2 \\
\hline \hline & & RegistrationDate : 2001-06-26 \\
ArticleHistory & $:$ & OnlineDate $\quad$ 2001-06-26 \\
\hline \hline ArticleCopyright & $:$ & BioMed Central Ltd2001 \\
\hline \hline ArticleGrants & $:$ & \\
\hline \hline ArticleContext & $:$ & 130592211 \\
\hline \hline
\end{tabular}




\section{Jonathan B Weitzman}

Email: jonathanweitzman@hotmail.com

STI-571 is an Abelson tyrosine kinase (Abl) inhibitor that is being tested in clinical trials to treat chronic myeloid leukemia (CML). A chromosomal translocation in CML patients results in production of the Bcr-Abl fusion protein, which is constitutively active and oncogenic. In the June 21 ScienceXpress, Gorre et al. report on the mechanism of relapse in STI-571 patients (Sciencexpress 2001, 10.1126/science.1062538). They found that patients in STI-571 remission had reactivated Bcr-Abl activity; 3 of the 11 patients had amplified copies of the oncogenic $B C R-A B L$ gene. Two thirds of patients tested harboured a single point mutation within the ATP-binding site of Bcr-Abl. Thus the $B C R$ $A B L$ gene appears important in both the initiation and the maintenance of tumorigenicity. Identifying mutated alleles may help to detect drug-resistant clones prior to clinical relapse.

\section{References}

1. Sti571: a gene product-targeted therapy for leukemia

2. ScienceXpress, [http://www.sciencexpress.org] 